\title{
CHAPTER 8 \\ COMPETITIVENESS OF THE INDUSTRY POTENTIAL: INFLUENCE OF FACTORS AND THEIR ESTIMATION
}

\section{Kovalenko-Marchenkova Ye. V.}

\section{INTRODUCTION}

The industry potential is an aggregated potential of enterprises that work inside of it. The industry potential determines its ability to selfdevelopment on a more qualitative basis in specific conditions of space and time, characterized by the action of certain factors. The competitiveness of the industry's potential we can determine as the multidimensional complex property of using certain resources, which is defined by its components and the nature of their interconnections, characterized by investment attractiveness, is formed under the influence of factors. The estimation of the competitiveness of the potential is the first step forward increasing the competitiveness of the national economy as a whole. The problem of the potential is studied in the works of different national and foreign scientists: A. Onishchenko, B. Paskhaver, E. Figurnov, V. Gusakov, A. Anchishkin, L. Kostyrko, L. Abalkin, K. Vobliy, A. Voronov, O. Fedonin, I. Repin, O. Oleksik, I. Olenko, N. Poberezhna, I. Lukinov, I. Dolzhanska, T. Zagorna, I. Ansoff, V. Shapoval, G. Gerasimchuk, R. Marushkov, L. Sosnenko, V. Kovalev, O. Volkov, M. Ivanov, Yu. Odegov, K. Andreev, B. Mochalova, L. Revutsky, E. Lapina, B. Bachevsky, O. Reshetnyak, and others are among them. The competitiveness is studied by T. Vyatkina and P. Vyatkin, M. Gelvanovsky, V. Zhukovsky, N. Pedchenko, K. Kuznetsova, R. Fatkhuddinov V. Khomyakov and other. N. Krasnokutskaya, A. Voronkova, A. Kvasko have researches about competitiveness of the potential in particular. Factors of competitiveness is discussed in works of I. Lifits, K. Seleznov, S. Savchuk and others. Such amount of works about competitiveness and competitiveness of potential formed the interest to this topic for forward research. 


\subsection{An overview of the essence of factors of the industry potential competitiveness}

The competitiveness of the industry's potential is influenced by many factors. That is why it is worth to clarify the essence of "industry potential competitiveness factor". The term "factor" is of Latin origin and is defined by scientists as a significant objective cause of a phenomenon, the influence of which determines the nature and individual features of the object of influence ${ }^{1}$.

The Statistical Dictionary, edited by M. Korolev, offers the following definitions of the concept of a factor:

1) the reason which is in a certain logical connection with the investigation;

2) a numerical value (stat. - "indicator"), which is in a certain quantitative relationship with another indicator;

3) in mathematical statistics - the internal evolution of an object, the reason, which is not directly observed but can be quantified ${ }^{2}$.

K. Seleznov lists the following properties of the factor:

- first, it can change its quantitative and qualitative characteristics when exposed to a particular phenomenon;

- secondly, the concept of factor includes a force that gives momentum to movement and changes the characteristics of the subject of influence;

- thirdly, the factor is the magnitude that at each instant of time has a point of influence on the object, the quantitative value of the impact and its orientation in space;

- fourth, the factor involved in the process of economic activity is an economic resource (asset), the remuneration of which is the relevant form of factor income;

- fifth, the property of the factor to generate income is not automatically realized but is provided if it is effectively used ${ }^{3}$.

Professor I. Lifits in his work defines the factor of competitiveness as the direct cause, the presence of which is necessary and sufficient to change one or more criteria of competitiveness ${ }^{4}$.

\footnotetext{
1 Лукинов О.В. Основные факторы конкурентного преимущества строительной организации : сб. науч. тр. Москва : МГСУ, 2003. С. 45-57.

${ }^{2}$ Королев М. А. Статистический словарь. Москва : Финансы и статистика, 1989. 620 с.

${ }^{3}$ Селезньова К.В. Обгрунтування факторів впливу на розвиток експортного потенціалу машинобудівного підприємства. Вісник Начіонального технічного університету «ХПI». Технічний прогрес та ефективність виробництва. 2013. № 45. С. 102-115.
} 
S. Savchuk proposes to understand the competitiveness factor as the arbitrary property of an economic environment or the economic entity itself, capable of influencing the process and results of the operation of that entity in a competitive environment. Thus, the author explains, competitiveness factors are a subset of the entity's viability factors in a competitive environment ${ }^{5}$.

Competition in the industry depends on the nature of the industry, as well as specific factors such as industrial policy, government relations, competition system, ability to analyze competitors.

Identifying the factors of potential competitiveness is a complex and important stage of work, as it is the factors that determine the development of each component of the industry's potential ${ }^{6}$.

Our research allowed to identify the main factors of competitiveness classification criteria for potential industry classification.

We have developed a classification of the factors of competitiveness of the industry's potential on various characteristics.

If we allocate all the factors of competitiveness of the industry potential depending on the field of origin, it is possible to distinguish internal and external factors.

Internal factors of industry competitiveness depend on the state of the industry and the enterprises that operate in this industry. Internal factors can be formed at the mezzo and micro levels. External factors do not depend on the characteristics of the industry and are formed at the macro-level ${ }^{7}$.

Factors, which are formed at the micro-level, are created at the level of the enterprises of the industry and depend on their organizational, managerial, resource, financial characteristics. The following factors can be internal: organizational and managerial factors; resource factors; production factors; socio-psychological factors; innovation and investment factors; information factors.

Factors of the mezzo level - factors that are created at the industry level and include: market factors; infrastructure factors; investment factors; legislative and legal factors; natural resource factors.

\footnotetext{
${ }^{4}$ Лифиц И.М. Формирование и оценка конкурентоспособности товаров и услуг : Учебное пособие для вузов. Юрайт-Издат. 2004. 335 с.

${ }^{5}$ Савчук С.И. Основы теории конкурентоспособности. ИПРЭЭИ НАН Украины. Мариуполь : Рената 2007. $520 \mathrm{c}$.

${ }^{6}$ Єфремова В.Б. Фактори впливу на конкурентоспроможність. Волин. ін-т економіки та менеджменту. URL: http://www.viem.edu.ua/konf6/art.php?id=0467 (дата звернення: 07.11.2019).

${ }^{7}$ Коваленко-Марченкова Є.В. Класифікація факторів конкурентоспроможності потенціалу галузі. Materials of the XIII International scientific and practical cconference «Science And Civilization - 2017》. Sheffield. 2017. Volume 2. C. 82-84.
} 
Macro-level factors are external factors that occur outside of enterprises and industries (at the national and global levels). This group of factors includes economic, social, political, legal conditions that arise under the influence of restrictive or stimulating measures by state bodies, banks, investment companies, public groups, political forces, public organizations, etc.

Factors, formed at the macro level, maybe the next:

political and legal factors; economic factors; environmental factors; social factors; external- economic factors.

Given the current pace of change for each factor, the creation of competitive potential is focused on the prospect and providing its flexibility. This result requires a detailed analysis of the factors of influence, taking into account the fact that individual components of the industry's potential do not respond equally to the change of these factors ${ }^{8}$.

It is interesting to divide the factors into two groups: factors of influence on the potential formation that determine the possible presence of competitive advantages, that is, contribute to their achievement; factors of influence on the usage of potential, which contributes to maintaining competitive advantages.

The main factors for achieving the competitiveness of the industry's potential include organizational-managerial, innovation-investment and production factors, market; scientific, technological, investment, economic, social and external economic factors ${ }^{9}$.

In addition, all the competitiveness factors of an industry's potential by the duration of impact can be classified into permanent (impact of which lasts for a long time) and variables (impact of which changes over time), as well as by nature of influence - factors of direct and indirect influence.

When analyzing the competitiveness factors of an industry's potential, it is important to consider how far their influence can be controlled. From this point of view, the factors of competitiveness of the potential can be uncontrolled, limited-controlled and controlled. Uncontrollable factors cannot be controlled not only at the industry level but also at the state one. Limited controllable factors can be controlled at

\footnotetext{
${ }^{8}$ Чумак Л.Ф. Фактори впливу на формування конкурентоспроможного потенціалу підприємств. Экономика и управление. 2011. № 1. С. 62-69.

${ }^{9}$ Коваленко-Марченкова Є.В. Класифікація факторів конкурентоспроможності потенціалу галузі. Materials of the XIII International scientific and practical cconference «Science And Civilization - 2017》. Sheffield. 2017. Volume 2. C. 82-84.
} 
the state level but are not affected at the industry level. For controlled factors, their impact is fully controlled at the industry level.

Some authors consider factors by their origin (natural and artificial factors), specialization (general and specialized), the intensity of influence (minor, significant and very significant) and its orientation (positive and negative). By importance, all factors of competitiveness of the industry's potential can be divided into primary and secondary ones $^{10,11,12}$.

For sure, each factor must be evaluated from the point of view of achievement and maintaining competitiveness, and for this purpose, the basic requirements for these indicators must be selected.

The analysis of the factors, influencing the competitiveness of the potential, provides time for forecasting opportunities, developing measures that will turn threats into any profitable opportunities.

\subsection{Methodical aspects of estimation the influence of factors on the competitiveness of the industry's potential}

The estimation of factors of the industry's potential competitiveness is a necessary tool for ensuring the competitiveness of the potential of any industry. For estimation of the influence of the factors of competitiveness of the potential of the industry, it is necessary to use specific methodological tools, which allows determining the necessary parameters for ensuring the competitiveness and its quantitative characteristics.

The competitiveness of the industry's potential depends on many factors, the first stage of estimating the influence of which is to identify the factors influencing the competitiveness of the potential of the industry.

The estimation of the influence of factors should begin with the identification of their list. With this aim, methods of scientific knowledge such as analogy, idealization, formalization, and systematization are applied. However, the analogy method does not provide reliable information about the factors of influence. The idealization method

\footnotetext{
${ }^{10}$ Селезньова К.В. Обгрунтування факторів впливу на розвиток експортного потенціалу машинобудівного підприємства. Вісник Національного технічного університету «ХПІ». Технічний прогрес та ефективність виробництва. 2013. № 45. С. 102-115.

11 Лифиц И.М. Формирование и оценка конкурентоспособности товаров и услуг : Учебное пособие для вузов. Юрайт-Издат, 2004. 335 с.

12 Сфремова В.Б. Фактори впливу на конкурентоспроможність. Волин. ін-т економіки та менеджменту. URL: http://www.viem.edu.ua/konf6/art.php?id=0467 (дата звернення: 07.11.2019).
} 
cannot be applied because no object would act as the standard. And formalization is related to the usage of mathematical apparatus and it is more appropriate in economic and mathematical modelling. Therefore, it is proposed to use a systematic method to identify the factors influencing the formation and usage of the industry's potential.

As a specific method of research, systematization is a cognitive process of ordering several disparate factors. The ordering is done by establishing the unity and difference of the elements, which have to be systematized, determining the location of each factor relative to each other. The result of systematization is an appropriate system of factors influencing the components of the formation and usage of the industry's potential. The advantage of using the systematization method in our study is the fact that as a result of systematization we can obtain an appropriate system of factors of positive and negative impact on the competitiveness of the potential of the construction industry (Figure 1).

Generalizing scientific views on competitiveness of the potential will help to systematize the factors that may influence the formation and usage of the potential and form a preliminary list on this basis.

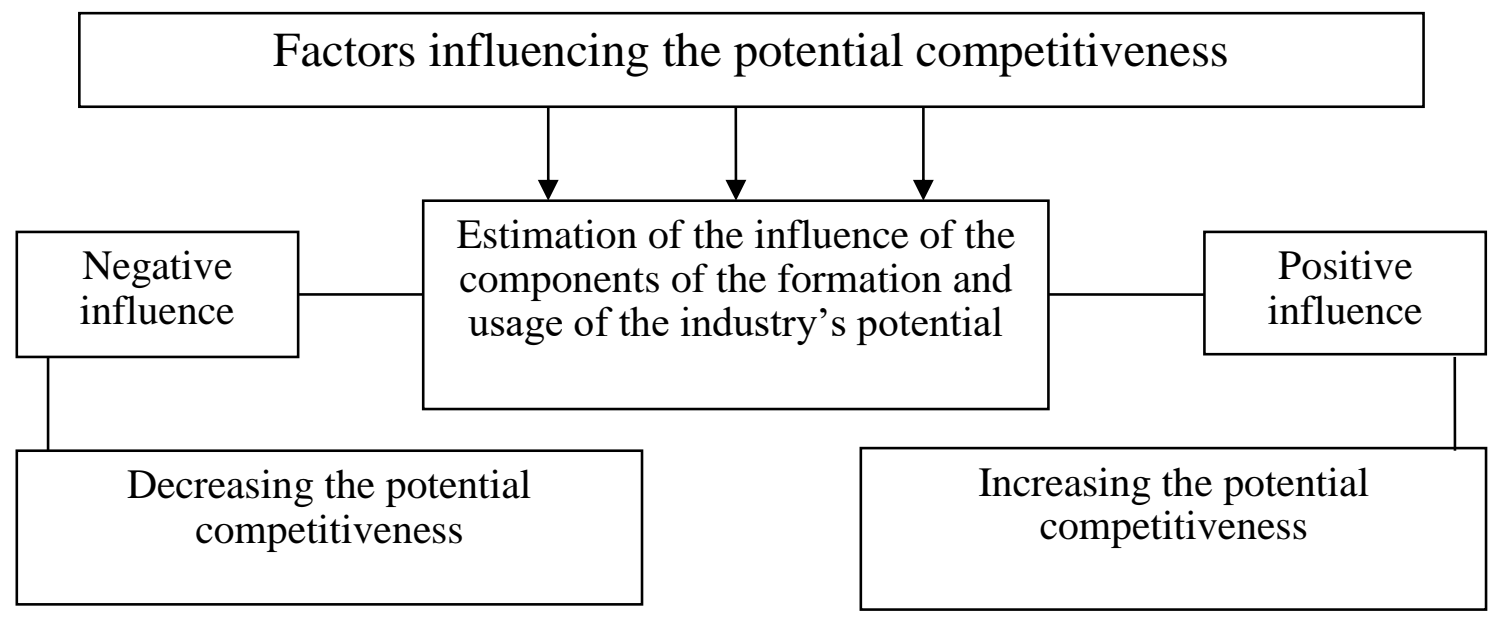

\section{Figure 1. The system of factors influencing the competitiveness of the industry's potential}

Source: built by the author

The next stage involves determining the most important factors that influence the formation and usage of the industry's potential, using the method of an expert survey. A list will be given to the experts, who will evaluate the factors and select the factors that influence the formation or usage of the potential of the industry. 
In the next stage, the overall impact of the most significant factors on the formation or usage of the potential of the industry should be estimated based on expert assessments.

This stage should include determining the sensitivity of the industry's potential components to the influence of external factors, estimating the impact of the most significant factors on the formation and usage of industry's potential considering components of the potential and determining the influence of the most relevant factors on the overall potential's formation and usage indicators considering sensitivity.

Objective estimation of the influence of factors on the formation and usage of the potential of the industry requires determining the sensitivity of the establishment of the components that have the greatest influence on the formation and usage of the industry's potential. In our previous research, we defined natural-resource, investment, scientifictechnical, intellectual and infrastructural components of the industry's potential $^{13}$. To establish the component that has the greatest influence on the change of the generalized indicator of the industry's potential formation, a factor analysis of the dependence of the change of the generalizing indicator of the formation on the change of the formation indicator for each component of the potential is proposed.

We propose to use the method of chain substitutions, the sequence of which is as follows ${ }^{14,15}$ :

Stage 1. The calculation of the actual and basic value of the generalizing indicator of the industry's potential formation in the analysed year is determined using the following formula:

$$
\begin{gathered}
I F^{t-1}=\frac{\sum_{i=1}^{I} I F_{1}^{t-1}}{I}=\frac{1}{\mathrm{I}} \cdot\left(I F_{1}^{t-1}+I F_{2}^{t-1}+I F_{3}^{t-1}+I F_{4}^{t-1}+I F_{5}^{t-1}\right), \\
I F^{t}=\frac{\sum_{i=1}^{I} \mathrm{I} F_{1}^{t}}{I}=\frac{1}{\mathrm{I}} \cdot\left(I F_{1}^{t}+I F_{2}^{t}+I F_{3}^{t}+I F_{4}^{t}+I F_{5}^{t}\right),
\end{gathered}
$$

where $I F^{t}$ and $I F^{t-1}$ - the basic and actual value of the generalizing indicator of the industry's potential formation;

$I F$ and $I F_{\mathrm{i}}^{t-1}$ - the basic and actual value of the generalizing indicator of the industry's potential formation by the i-th component;

\footnotetext{
${ }^{13}$ Коваленко-Марченкова Є.В. Складові потенціалу будівельної галузі як основа його конкурентоспроможності. Причорноморські економічні студії. 2017. Вип. 15. С. $36-39$.

${ }^{14}$ Савицька Г.В. Економічний аналіз діяльності підприємства : Навч. посіб. 3-те вид., випр. і доп. Київ : Знання, 2007. 668 с.

${ }^{15}$ Бутинець Ф.Ф. Економічний аналіз. Житомир : ПП «Рута», 2003. 680 с.
} 
$I F_{1}^{t}$ and $I F_{1}^{t-1}$ - the basic and actual value of the generalizing indicator of the industry's potential formation by the natural-resource component;

$I F_{2}^{t}$ and $I F_{2}^{t-1}$ - the basic and actual value of the generalizing indicator of the industry's potential formation by the investment component;

$I F_{3}^{t}$ and $I F_{3}^{t-1}$ - the basic and actual value of the generalizing indicator of the industry's potential formation by the scientific and technical component;

$I F_{4}^{t}$ and $I F_{4}^{t-1}$ - the basic and actual value of the generalizing indicator of the industry's potential formation by the intellectual component;

$I F_{5}^{t}$ and $I F_{5}^{t-1}$ - the basic and actual value of the generalizing indicator of the industry's potential formation by the infrastructural component;

$i=\overline{1, I}$ - number of the component of the industry's potential;

$t=\overline{1, T}-$ the number of the year under study.

Stage 2. The calculation of the conditional values of the generalizing indicator of the industry's potential formation in this year is determined using the following formulas:

a) The first conditional value of the generalized indicator of the industry's potential formation in this year, which is calculated on the basis of the actual value of the indicator of the industry's potential formation by natural-resource component and the basic values of the indicators of industry's potential formation by other components:

$$
I F_{1 \text { conditional }}{ }^{t}=\frac{1}{\mathrm{I}} \cdot\left(I F_{1}^{t}+I F_{2}^{t-1}+I F_{3}^{t-1}+I F_{4}^{t-1}+I F_{5}^{t-1}\right),
$$

where $I F_{1 \text { conditional }}{ }^{t}-$ the first conditional value of generalizing indicator of the industry's potential formation.

b) The second conditional value of the generalizing indicator of the industry's potential formation in this year, which is calculated on the basis of the actual value of the indicator of the industry's potential formation by natural-resource and investment component and the basic values of the indicators of industry's potential formation by other components:

$$
I F_{2 \text { conditional }}^{t}=\frac{1}{\mathrm{I}} \cdot\left(I F_{1}^{t}+I F_{2}^{t-1}+I F_{3}^{t-1}+I F_{4}^{t-1}+I F_{5}^{t-1}\right),
$$


where $I F_{2 \text { conditional }}{ }^{t}$ - the second conditional value of generalizing indicator of the industry's potential formation.

c) The third conditional value of the generalizing indicator of the industry's potential formation in this year, which is calculated on the basis of the actual value of the indicator of the industry's potential formation by natural-resource, investment and scientific-technical component and the basic values of the indicators of industry's potential formation by other components:

$$
I F_{3 \text { conditional }}{ }^{t}=\frac{1}{\mathrm{I}} \cdot\left(I F_{1}^{t}+I F_{2}^{t-1}+I F_{3}^{t-1}+I F_{4}^{t-1}+I F_{5}^{t-1}\right),
$$

where $I F_{3 c o n d i t i o n a l}{ }^{t}$ - the third conditional value of generalizing indicator of the industry's potential formation.

d) The fourth conditional value of the generalized indicator of the industry's potential formation in this year, which is calculated on the basis of the actual value of the indicator of the industry's potential formation by natural-resource, investment, scientific-technical and intellectual component and the basic values of the indicators of industry's potential formation by infrastructural components:

$$
I F_{4 \text { conditional }}{ }^{t}=\frac{1}{\mathrm{I}} \cdot\left(I F_{1}^{t}+I F_{2}^{t-1}+I F_{3}^{t-1}+I F_{4}^{t-1}+I F_{5}^{t-1}\right) \text {, }
$$

where $I F_{4 c o n d i t i o n a l}{ }^{t}$ - the fourth conditional value of generalizing indicator of the industry's potential formation.

Stage 3. Determination of the change of the generalizing indicator of the industry's potential formation under the influence of the change of indicators by the components:

a) Change of the generalizing indicator of the industry's potential formation under the influence of the change of indicators by the naturalresource component:

$$
\Delta \mathrm{I} F_{1}{ }^{t}=I F_{1 \text { conditional }}{ }^{t}-\mathrm{I} F^{t-1}
$$

b) Change of the generalizing indicator of the industry's potential formation under the influence of the change of indicators by investment component:

$$
\Delta \mathrm{IF}_{2}{ }^{t}=I F_{2 \text { conditional }}{ }^{t}-I F_{1 \text { conditional }}{ }^{t}
$$

c) Change of the generalizing indicator of the industry's potential formation under the influence of the change of indicators by scientifictechnical component:

$$
\Delta \mathrm{I} F_{3}{ }^{t}=I F_{3 \text { conditional }}{ }^{t}-I F_{\text {2conditional }}{ }^{t}
$$


d) Change of the generalizing indicator of the industry's potential formation under the influence of the change of indicators by intellectual component:

$$
\Delta \mathrm{I} F_{4}{ }^{t}=I F_{4 \text { conditional }}{ }^{t}-I F_{3 \text { conditional }}{ }^{t}
$$

e) Change of the generalizing indicator of the industry's potential formation under the influence of the change of indicators by infrastructural component:

$$
\Delta \mathrm{I} F_{5}{ }^{t}=I F_{5 \text { conditional }}{ }^{t}-I F_{4 \text { conditional }}{ }^{t}
$$

Stage 4 . Determining the overall change and verifying the accuracy of the calculations:

$$
\Delta I F^{t}=I F^{t}-I F^{t-1}=\Delta I F_{1}{ }^{t}+\Delta I F_{2}{ }^{t}+\Delta I F_{3}{ }^{t}+\Delta I F_{4}{ }^{t}+\Delta I F_{5}{ }^{t}
$$

The calculation of the change of generalizing indicator of formation depending on the change of formation indicators for each component of potential is carried out for a number of years. After the calculations, using the methods of economic analysis, we determine the annual average deviation (absolute and linear) of the generalised indicator of the industry's potential as a whole and due to the influence of each component on its change $\mathrm{e}^{16,17,18}$ :

a) average absolute deviation:

- of a generalizing indicator of the industry's potential formation as a whole:

$$
\overline{\Delta I F}=\frac{\sum_{t=2}^{T} \Delta I F^{t}}{T-1} ;
$$

- of a generalizing indicator of the industry's potential formation due to changes in the indicator of formation by the natural-resource component:

$$
\overline{\Delta I F_{1}}=\frac{\sum_{t=2}^{T} \Delta I F_{1}{ }^{t}}{T-1} ;
$$

- of a generalizing indicator of the industry's potential formation due to changes in the indicator of formation by the investment component:

\footnotetext{
${ }^{16}$ Коростенко Т.Д. Економічний аналіз і діагностика стану сучасного підприємства : навчальний посібник. Київ : Центр навчальної літератури, 2005. 400 с.

${ }^{17}$ Мних С.В. Економічний аналіз діяльності підприємства: підручник. Київ : Київ. нац. торг.-екон. ун-т. 2008. 514 с.

18 Прокопенко І.Ф. Методика і методологія економічного аналізу : навч. пос. Київ : Центр учбової літератури. 2008. 430 с.
} 


$$
\overline{\Delta I F_{2}}=\frac{\sum_{t=2}^{T} \Delta I F_{2}{ }^{t}}{T-1} ;
$$

- of a generalizing indicator of the industry's potential formation due to changes in the indicator of formation by the scientific-technical component:

$$
\overline{\Delta I F_{3}}=\frac{\sum_{t=2}^{T} \Delta I F_{3}{ }^{t}}{T-1} ;
$$

- of a generalizing indicator of the industry's potential formation due to changes in the indicator of formation by the intellectual component:

$$
\overline{\Delta I F_{4}}=\frac{\sum_{t=2}^{T} \Delta I F_{4}{ }^{t}}{T-1} ;
$$

- of a generalizing indicator of the industry's potential formation due to changes in the indicator of formation by the infrastructural component:

$$
\overline{\Delta I F_{5}}=\frac{\sum_{t=2}^{T} \Delta I F_{5}{ }^{t}}{T-1} ;
$$

b) mean linear deviation:

- of a generalizing indicator of the industry's potential formation as a whole:

$$
|\overline{\Delta I F}|=\frac{\sum_{t=2}^{T}\left|\Delta I F^{t}\right|}{T-1} ;
$$

- of a generalizing indicator of the industry's potential formation due to changes of the indicator of formation by the natural-resource component:

$$
\left|\overline{\Delta I F_{1}}\right|=\frac{\sum_{t=2}^{T} \mid \Delta I F_{1}{ }^{t}}{T-1} ;
$$

- of a generalizing indicator of the industry's potential formation due to changes of the indicator of formation by the investment component:

$$
\left|\overline{\Delta I F_{2}}\right|=\frac{\sum_{t=2}^{T}\left|\Delta I F_{2}{ }^{t}\right|}{T-1} ;
$$

- of a generalizing indicator of the industry's potential formation due to changes of the indicator of formation by the scientific-technical component:

$$
\left|\overline{\Delta I F_{3}}\right|=\frac{\sum_{t=2}^{T}\left|\Delta I F_{3}{ }^{t}\right|}{T-1}
$$


- of a generalizing indicator of the industry's potential formation due to changes of the indicator of formation by the intellectual component:

$$
\left|\overline{\Delta I F_{4}}\right|=\frac{\sum_{t=2}^{T}\left|\Delta I F_{4}{ }^{t}\right|}{T-1} ;
$$

- of a generalizing indicator of the industry's potential formation due to changes of the indicator of formation by the infrastructural component:

$$
\left|\overline{\Delta I F_{5}}\right|=\frac{\sum_{t=2}^{T} \mid \Delta I F_{5}{ }^{t}}{T-1} ;
$$

To establish the component that has the greatest influence on the change of the generalizing indicator of the industry's potential usage, a factor analysis of the dependence of the change of the generalization indicator of the usage on the change of the usage indicator for each component of the potential is proposed.

We propose to use the method of chain substitutions:

Stage 1. The calculation of the actual and basic value of the generalizing indicator of the industry's potential usage in the analysed year is determined using the following formula:

$$
\begin{gathered}
I U^{t-1}=\frac{\sum_{i=1}^{I} I U_{\mathrm{i}}^{t-1}}{I}=\frac{1}{\mathrm{I}} \cdot\left(I U_{1}^{t-1}+I U_{2}^{t-1}+I U_{3}^{t-1}+I U_{4}^{t-1}+I U_{5}^{t-1}\right), \\
I U^{t}=\frac{\sum_{i=1}^{I} I U_{\mathrm{i}}^{t}}{I}=\frac{1}{\mathrm{I}} \cdot\left(I U_{1}^{t}+I U_{2}^{t}+I U_{3}^{t}+I U_{4}^{t}+I U_{5}^{t}\right),
\end{gathered}
$$

where $I U^{t}$ and $I U^{t-1}$ - the basic and actual value of the generalizing indicator of the industry's potential usage;

$I U$ and $I U_{\mathrm{i}}^{t-1}$ - the basic and actual value of the generalizing indicator of the industry's potential usage by the i-th component;

$I U_{1}^{t}$ and $I U_{1}^{t-1}$ - the basic and actual value of the generalizing indicator of the industry's potential usage by the natural-resource component;

$I U_{2}^{t}$ and $I U_{2}^{t-1}$ - the basic and actual value of the generalizing indicator of the industry's potential usage by the investment component;

$I U_{3}^{t}$ and $I U_{3}^{t-1}$ - the basic and actual value of the generalizing indicator of the industry's potential usage by the scientific and technical component;

$I U_{4}^{t}$ and $I U_{4}^{t-1}$ - the basic and actual value of the generalizing indicator of the industry's potential usage by the intellectual component; 
$I U_{5}^{t}$ and $I U_{5}^{t-1}$ - the basic and actual value of the generalizing indicator of the industry's potential usage by the infrastructural component;

$i=\overline{1, I}$ - number of the component of the industry's potential;

$t=\overline{1, T}-$ the number of the year under study.

Stage 2. The calculation of the conditional values of the generalizing indicator of the industry's potential usage in this year is determined using the following formulas:

a) The first conditional value of the generalizing indicator of the industry's potential usage in this year, which is calculated on the basis of the actual value of the indicator of the industry's potential usage by natural-resource component and the basic values of the indicators of industry's potential usage by other components:

$$
I U_{1 \text { conditional }}{ }^{t}=\frac{1}{\mathrm{I}} \cdot\left(I U_{1}^{t}+I U_{2}^{t-1}+I U_{3}^{t-1}+I U_{4}^{t-1}+I U_{5}^{t-1}\right),
$$

where $I U_{1 \text { conditional }}{ }^{t}$ - the first conditional value of generalizing indicator of the industry's potential usage

b) The second conditional value of the generalizing indicator of the industry's potential usage in this year, which is calculated on the basis of the actual value of the indicator of the industry's potential usage by natural-resource and investment component and the basic values of the indicators of industry's potential usage by other components:

$$
I U_{\text {2conditional }}{ }^{t}=\frac{1}{\mathrm{I}} \cdot\left(I U_{1}^{t}+I U_{2}^{t-1}+I U_{3}^{t-1}+I U_{4}^{t-1}+I U_{5}^{t-1}\right),
$$

where $I U_{2 \text { conditional }}{ }^{t}$ - the second conditional value of generalizing indicator of the industry's potential formation.

c) The third conditional value of the generalizing indicator of the industry's potential formation in this year, which is calculated on the basis of the actual value of the indicator of the industry's potential formation by natural-resource, investment and scientific-technical component and the basic values of the indicators of industry's potential formation by other components:

$$
I U_{3 \text { conditional }}{ }^{t}=\frac{1}{\mathrm{I}} \cdot\left(I U_{1}^{t}+I U_{2}^{t-1}+I U_{3}^{t-1}+I U_{4}^{t-1}+I U_{5}^{t-1}\right),
$$

where $I U_{3 \text { conditional }}{ }^{t}$ - the third conditional value of generalizing indicator of the industry's potential formation. 
d) The fourth conditional value of the generalizing indicator of the industry's potential formation in this year, which is calculated on the basis of the actual value of the indicator of the industry's potential formation by natural-resource, investment, scientific-technical and intellectual component and the basic values of the indicators of industry's potential formation by infrastructural components:

$$
I U_{4 \text { conditional }}{ }^{t}=\frac{1}{\mathrm{I}} \cdot\left(I U_{1}^{t}+I U_{2}^{t-1}+I U_{3}^{t-1}+I U_{4}^{t-1}+I U_{5}^{t-1}\right),
$$

where $I U_{4 \text { conditional }}{ }^{t}$ - the fourth conditional value of generalizing indicator of the industry's potential formation.

Stage 3. Determination of the change of the generalizing indicator of the industry's potential usage under the influence of the change of indicators by the components:

a) Change of the generalized generalizing indicator of the industry's potential usage under the influence of the change of indicators by the natural- resource component:

$$
\Delta U_{1}^{t}=I U_{1 \text { conditional }}{ }^{t}-I U^{t-1}
$$

b) Change of the generalizing indicator of the industry's potential usage under the influence of the change of indicators by investment component:

$$
\Delta \mathrm{I}_{2}{ }^{t}=I U_{2 \text { conditional }}{ }^{t}-I U_{1 \text { conditional }}{ }^{t}
$$

c) Change of the generalizing indicator of the industry's potential usage under the influence of the change of indicators by scientifictechnical component:

$$
\Delta \mathrm{I}_{3}{ }^{t}=I U_{3 \text { conditional }}{ }^{t}-I U_{2 \text { conditional }}{ }^{t}
$$

d) Change of the generalizing indicator of the industry's potential usage under the influence of the change of indicators by intellectual component:

$$
\Delta \mathrm{I}_{4}{ }^{t}=I U_{4 \text { conditional }}{ }^{t}-I U_{3 \text { conditional }}{ }^{t}
$$

e) Change of the generalizing indicator of the industry's potential usage under the influence of the change of indicators by infrastructural component:

$$
\Delta \mathrm{I}_{5}{ }^{t}=I U_{5 \text { conditional }}{ }^{t}-I U_{4 \text { conditional }}{ }^{t}
$$


Stage 4. Determining the overall change and verifying the accuracy of the calculations:

$$
\Delta I U^{t}=I U^{t}-I U^{t-1}=\Delta U^{t}+\Delta I U_{2}{ }^{t}+\Delta I U_{3}{ }^{t}+\Delta U^{t}+\Delta I U_{5}{ }^{t}
$$

The calculation of the change of generalizing indicator of usage depending on the change of formation indicators for each component of potential is carried out for a number of years. After the calculations, using the methods of economic analysis, we determine the annual average deviation of the generalizing indicator of the industry's potential as a whole and due to the influence of each component on its change ${ }^{19,20,21}$ :

a) average absolute deviation:

- of a generalizing indicator of the industry's potential usage as a whole:

$$
\overline{\Delta I U}=\frac{\sum_{t=2}^{T} \Delta I U^{t}}{T-1}
$$

- of a generalizing indicator of the industry's potential usage due to changes of the indicator of formation by the natural-resource component:

$$
\overline{\Delta I U_{1}}=\frac{\sum_{t=2}^{T} \Delta I U_{1}{ }^{t}}{T-1} ;
$$

- of a generalizing indicator of the industry's potential formation due to changes of the indicator of formation by the investment component:

$$
\overline{\Delta I U_{2}}=\frac{\sum_{t=2}^{T} \Delta I U_{2}{ }^{t}}{T-1} ;
$$

- of a generalizing indicator of the industry's potential formation due to changes of the indicator of formation by the scientific-technical component:

$$
\overline{\Delta I U_{3}}=\frac{\sum_{t=2}^{T} \Delta I U_{3}{ }^{t}}{T-1}
$$

\footnotetext{
${ }^{19}$ Коростенко Т.Д. Економічний аналіз і діагностика стану сучасного підприємства : навчальний посібник. Київ : Центр навчальної літератури, 2005. 400 с.

${ }^{20}$ Мних Є.В. Економічний аналіз діяльності підприємства: підручник. Київ : Київ. нац. торг.-екон. нн-т, 2008. $514 \mathrm{c}$.

${ }^{21}$ Прокопенко І.Ф. Методика і методологія економічного аналізу : навч. пос. Київ : Центр учбової літератури, 2008. 430 c.
} 
- of a generalizing indicator of the industry's potential formation due to changes of the indicator of formation by the intellectual component:

$$
\overline{\Delta I U_{4}}=\frac{\sum_{t=2}^{T} \Delta I U_{4}{ }^{t}}{T-1} ;
$$

- of a generalizing indicator of the industry's potential formation due to changes of the indicator of formation by the infrastructural component:

$$
\overline{\Delta I U_{5}}=\frac{\sum_{t=2}^{T} \Delta I U_{5}{ }^{t}}{T-1} ;
$$

b) mean linear deviation: whole:

- of a generalizing indicator of the industry's potential usage as a

$$
|\overline{\Delta I U}|=\frac{\sum_{t=2}^{T}\left|\Delta I U^{t}\right|}{T-1} ;
$$

- of a generalizing indicator of the industry's potential formation due to changes in the indicator of usage by the natural-resource component:

$$
\left|\overline{\Delta I U_{1}}\right|=\frac{\sum_{t=2}^{T}\left|\Delta I U_{1}{ }^{t}\right|}{T-1} ;
$$

- of a generalizing indicator of the industry's potential formation due to changes in the indicator of usage by the investment component:

$$
\left|\overline{\Delta I U_{2}}\right|=\frac{\sum_{t=2}^{T}\left|\Delta I U_{2}{ }^{t}\right|}{T-1} ;
$$

- of a generalizing indicator of the industry's potential formation due to changes in the indicator of usage by the scientific-technical component:

$$
\left|\overline{\Delta I U_{3}}\right|=\frac{\sum_{t=2}^{T}\left|\Delta I U_{3}{ }^{t}\right|}{T-1} ;
$$

- of a generalizing indicator of the industry's potential formation due to changes in the indicator of usage by the intellectual component:

$$
\left|\overline{\Delta I U_{4}}\right|=\frac{\sum_{t=2}^{T}\left|\Delta I U_{4}{ }^{t}\right|}{T-1} ;
$$

- of a generalizing indicator of the industry's potential formation due to changes in the indicator of usage by the infrastructural component: 


$$
\left|\overline{\Delta I U_{5}}\right|=\frac{\sum_{t=2}^{T}\left|\Delta I U_{5}{ }^{t}\right|}{T-1}
$$

\section{CONCLUSIONS}

Summarizing the information above we can conclude that competitiveness of the industry potential is formed under the influence of different factors of micro-, mezzo- and macro-levels of economy. The classification of the competitiveness factors of the industry's potential on various characteristics is developed. Factors of industry's potential competitiveness have to be evaluated from the point of view of achievement and maintaining the competitiveness. The analysis of the factors is needed for forecasting opportunities, developing measures that will turn threats into any profitable opportunities. The methodological approach to estimating the influence of factors on the industry potential competitiveness using the methods of factor analysis is developed.

A methodological approach to the estimation of the competitiveness of the potential of the industry considering factors and components of the potential is proposed. The main purpose of estimating the competitiveness of the industry's potential is to identify the level of competitiveness considering the degree of its formation and efficiency of usage, which can be the basis for modeling the competitive strategy of the industry.

Indicator methods for estimating the competitiveness of the potential of the industry make it possible to evaluate integrally the competitiveness of the potential by its components, which allows to consider the complex nature of the potential competitiveness concept.

\section{SUMMARY}

The research is devoted to studying the competitiveness of industry potential, which is formed under the influence of micro-, mezzo-, macrolevel factors. The essence, particularly, of the factors of potential competitiveness is explored. It is considered as the reason, the presence of which is necessary and sufficient to change one or more criteria of competitiveness. The classification of the factors of competitiveness of the industry's potential on various characteristics is represented. The system of factors influencing the competitiveness of the industry's potential is given. For estimation the competitiveness of the industry 
potential, including the influence of competitiveness factors on the potential formation and usage considering components of the potential, the methodological approach is developed.

\section{REFERENCES:}

1. Бутинець Ф.Ф. Економічний аналіз. Житомир : ПП «Рута». 2003. $680 \mathrm{c}$.

2. Єфремова В.Б. Фактори впливу на конкурентоспроможність. Волин. ін-т економіки та менеджменту. URL: http://www.viem.edu.ua/ konf6/art.php?id=0467 (дата звернення: 7.11.2019).

3. Коваленко-Марченкова Є.В. Класифікація факторів конкурентоспроможності потенціалу галузі. Materials of the XIII International scientific and practical cconference «Science And Civilization - 2017». Sheffield. 2017. Volume 2. C. 82-84.

4. Коваленко-Марченкова Є.В. Складові потенціалу будівельної галузі як основа його конкурентоспроможності. Причорноморські економічні студіі. 2017. Вип. 15. С. 36-39.

5. Королев М.А. Статистический словарь. Москва : Финансы и статистика, 1989. 620 с.

6. Коростенко Т.Д. Економічний аналіз і діагностика стану сучасного підприємства : навчальний посібник. Київ : Центр навчальної літератури, 2005. 400 с.

7. Лифиц И.М. Формирование и оценка конкурентоспособности товаров и услуг : Учебное пособие для вузов. ЮрайтИздат, 2004. 335 с.

8. Лукинов О.В. Основные факторы конкурентного преимущества строительной организации : сб. науч. тр. Москва : МГСУ. 2003. C. 45-57.

9. Мних Є.В. Економічний аналіз діяльності підприємства : підручник. Київ : Київ. нац. торг.-екон. ун-т, 2008. 514 с.

10. Прокопенко І.Ф. Методика i методологія економічного аналізу : навч. пос. Київ : Центр учбової літератури, 2008. 430 с.

11. Савицька Г.В. Економічний аналіз діяльності підприємства : навч. посіб. 3-тє вид., випр. і доп. Київ : Знання, 2007. 668 с.

12. Савчук С.И. Основы теории конкурентоспособности. ИПРЭЭИ НАН Украины. Мариуполь : Рената, 2007. 520 с.

13. Селезньова К.В. Обгрунтування факторів впливу на розвиток експортного потенціалу машинобудівного підприємства. 
Вісник Національного технічного університету «ХПI». Технічний прогрес та ефективність виробнищтва. 2013. № 45. С. 102-115.

14. Чумак Л.Ф. Фактори впливу на формування конкурентоспроможного потенціалу підприємств. Экономика и управление. 2011. № 1. C. 62-69.

Information about the author: Kovalenko-Marchenkova Ye.V. Ph.D in Economics, Associate Professor, Department of Accounting, Economics and Entrepreneurship, Prydniprovs'ka State Academy of Civil Engineering and Architecture, Ukraine 